Mgr Łukasz Skoczylas*

\title{
AKTUALNA WSPÓŁPRACA TRANSGRANICZNA RZECZYPOSPOLITEJ POLSKIEJ MODELUJACA AKTYWNOŚĆ MIĘDZYNARODOWĄ SAMORZĄDÓW
}

W niniejszej pracy przedstawiona zostanie aktualna problematyka współpracy transgranicznej z wybranymi sąsiadami Rzeczypospolitej Polskiej, odbywająca się w ramach gremiów międzyrządowych, nadzorowanych przez Ministerstwo Spraw Wewnętrznych Rzeczypospolitej Polskiej.

Na wstępie zaznaczyć warto, iż współpraca transgraniczna RP nie ogranicza się wyłącznie do jej sąsiadów. Aktywnie rozwija się kooperacja z Belgią, Łotwą i Estonią. Dodatkowo, umowy o współpracy międzyregionalnej zawarte zostały również z Gruzją, Kirgistanem i Uzbekistanem. W poniższym artykule ze względu na ograniczenia objętościowe zostaną omówione tylko przykłady współpracy transgranicznej z państwami graniczącymi bezpośrednio z Polską.

Współpraca transgraniczna ze strony polskiej przebiega zarówno na poziomie samorządowym jak i rządowym. Samorządy wszystkich szczebli realizują projekty współpracy ze swoimi transgranicznymi partnerami. Rolą gremiów międzyrządowych takich jak komisje i rady jest stymulacja tejże współpracy, stwarzanie warunków dla jej rozwoju oraz dbanie o jej zgodność z polityką zagraniczną państwa polskiego. Dzięki pracy komisji i rad międzyrządowych możliwe jest modelowanie stosunków międzyregionalnych, w tym między jednostkami samorządu terytorialnego i ich odpowiednikami za granicą. Dodatkowo warto zauważyć, iż instytucje samorządowe i rządowe uzupełniają się wzajemnie, tworząc wspólny front na rzecz współpracy transgranicznej. W tym kontekście należy zauważyć rosnącą aktywność samorządów na tym polu i wzrastającą w związku z tym potrzebę prac w ramach gremiów międzyrządowych. ${ }^{114}$

\footnotetext{
* $\quad$ Pracownik Wydziału Współpracy Transgranicznej w Ministerstwie Spraw Wewnętrznych.

114 M. Bonikowska, G. Lipski, Ż. Kazimierz, Polska polityka zagraniczna. Perspektywa samorządów i obywateli, s. 8-13, tryb dostępu oficjalna strona internetowa Ministerstwa Spraw Zagranicznych: http://www.msz.gov.pl/resource/e53ba3e8-cc81-408c-9882-8b9082bed2d3:JCR, dnia 07.12.2012 r.
} 
Ogólną regulacją, na podstawie której odbywa się współpraca Polski z jej sąsiadami, jest Konwencja madrycka o współpracy transgranicznej przyjęta w Madrycie w maju 1980 r. Polska ratyfikowała ją w 1993 r. ${ }^{115} \mathrm{~W}$ art. 2 znajdujemy następującą definicję współpracy transgranicznej:

„Za współpracę transgraniczną uważa się w myśl niniejszej konwencji każde wspólnie podjęte działanie mające na celu umocnienie i dalszy rozwój sąsiedzkich kontaktów między wspólnotami i władzami terytorialnymi dwóch lub większej liczby Umawiających się Stron, jak również zawarcie porozumień i przyjęcie uzgodnień koniecznych do realizacji takich zamierzeń. Współpraca transgraniczna ograniczona jest ramami właściwości wspólnot i władz terytorialnych, w sposób określony przez prawo wewnętrzne. Niniejsza konwencja nie narusza zakresu i rodzaju tej właściwości”.

Współpraca transgraniczna z sąsiadami Rzeczypospolitej Polskiej prowadzona jest poprzez komisje lub rady międzyrządowe, których celem jest katalizacja i kanalizacja współpracy regionalnej oraz rozwiązywanie wspólnych problemów pojawiających się w rejonach przygranicznych obu państw.

Kraje sąsiadujące, z którymi prowadzona jest współpraca transgraniczna, można podzielić na dwie grupy:

- kraje członkowskie Unii Europejskiej;

- kraje spoza Unii Europejskiej, czyli kraje Partnerstwa Wschodniego UE i Rosję.

W radach i komisjach zauważyć można koncentrację tematyczną w następujących aspektach:

- przygranicznym, zajmującym się problematyką związaną stricte z przekraczaniem i infrastrukturą granicy państwowej;

- międzyregionalnym, obejmującym swoim zakresem problematykę związaną z szeroko rozumianą kooperacją regionów (w tym samorządową).

Jeśli wziąć pod uwagę bardziej szczegółową typologię, możemy wyróżnić następujące koncentracje tematyczne w ramach rad i komisji: transportową, przejść granicznych (z państwami nieczłonkowskimi UE), planowania przestrzennego, współpracy i wzajemnej pomocy podczas katastrof i klęsk żywiołowych lub innych poważnych wypadków, współpracy regionalnej w ramach euroregionów i europejskich ugrupowań współpracy terytorialnej, współpracy gospodarczej, ochrony środowiska, ochrony zdrowia i ratownictwa medycznego, edukacji i kultury. Należy jednocześnie pamiętać, że powyżej przytoczone typologie są jedynie przykładem schematycznym i w przypadku każdego gremium międzyrządowego ulegają zmia-

115 Europejska konwencja ramowa o współpracy transgranicznej pomiędzy wspólnotami i władzami terytorialnymi przyjęta w Madrycie w maju 1980 r. (Dz.U. z 1993 r. Nr 61, poz. 287). 
nom związanym z konkretną problematyką pojawiającą się we współpracy z danym partnerem.

Posiedzenia gremiów międzyrządowych kończą się podpisaniem wspólnego dokumentu (np. protokołu, czy komunikatu), który stanowi podsumowanie osiągnięć gremium i uwypuklenie wspólnie zidentyfikowanych problemów. Dokument ten bywa później uwzględniany w konsultacjach międzyrządowych najwyższego szczebla, sygnalizuje on również kierunek działań, który powinien być uwzględniony przez właściwe instytucje rządowe i samorządowe obu państw.

\section{Współpraca transgraniczna z Republiką Federalną Niemiec}

Jak już wspomniano na wstępie, Rzeczpospolita Polska Konwencję madrycką o współpracy transgranicznej przyjęła do swojego porządku prawnego w 1993 r., tym niemniej początek współpracy transgranicznej rozpoczął się kilka lat wcześniej wraz z transformacją systemów polityczno-ekonomicznych dawnych demokracji ludowych.

Pierwszą umową w ramach której poruszony został wątek współpracy transgranicznej, jest Traktat między RP a RFN o dobrym sąsiedztwie i przyjaznej współpracy zawarty 17 czerwca 1991 roku. ${ }^{116} \mathrm{~W}$ art. 12 wspomnianego traktatu czytamy:

„1. Umawiające się Strony przywiązują duże znaczenie do partnerskiej współpracy między regionami, miastami, gminami i innymi jednostkami terytorialnymi, w szczególności na obszarach przygranicznych.

2. Umawiające się Strony będą ułatwiać i wspierać tę współpracę we wszystkich dziedzinach, w szczególności działalność Komisji międzyrządowej do spraw współpracy regionalnej i przygranicznej."

Na podstawie tego Traktatu utworzona została Polsko-Niemiecka Komisja Międzyrządowa ds. Współpracy Regionalnej i Przygranicznej. Do dnia dzisiejszego odbyły się jej 23 posiedzenia. Ostatnie miało miejsce 17-18 września 2012 r. w Erfurcie, na terytorium dzisiejszych Niemiec.

Warty podkreślenia szczególnie w ostatnich latach jest dynamiczny rozwój współpracy RP z Niemcami. W tym kontekście należy zwrócić uwagę na dużą liczbę zawiązywanych nowych umów i porozumień. Jako przykładowe można wskazać:

- Umowę ramową między Rzeczpospolitą Polską a Republiką Federalną Niemiec o współpracy transgranicznej w ratownictwie medycznym, ${ }^{117}$

\footnotetext{
116 Traktat między Rzeczpospolitą a Republiką Federalną Niemiec o dobrym sąsiedztwie i przyjaznej współpracy, podpisany 17 czerwca 1991 r. (Dz.U. z 1992 r. Nr 14, poz. 56).

117 Aktualnie Umowa ta przeszła proces ratyfikacji w Parlamencie RP i oczekuje na podpis Prezydenta RP - tryb dostępu: http://www.sejm.gov.pl/sejm7.nsf/PrzebiegProc.xsp?nr=721, dnia 07.12.2012 r.
} 
- Umowę między Rzeczpospolitą Polską a Republiką Federalną Niemiec o współpracy w ruchu kolejowym przez polsko-niemiecką granicę państwową, ${ }^{118}$

- Wymianę not w zakresie zawarcia Porozumienia między Rządem Rzeczypospolitej Polskiej a Rządem Republiki Federalnej Niemiec o ustanowieniu Polsko-Niemieckiego Centrum Współpracy Służb Granicznych, Policyjnych i Celnych w Świecku. ${ }^{119}$

Komisja pracuje na podstawie regulaminu z dnia 22 kwietnia 1991 r. ${ }^{120}$ oraz noty dyplomatycznej z dnia 17 czerwca $1991 \mathrm{r} .{ }^{121} \mathrm{~W}$ opinii autora niniejszej publikacji zarówno regulamin jak i wspomniana nota, znacznie odbiegają od aktualnie ustalonych zwyczajów procedowania Komisji i w związku z tym wymagają pilnych zmian.

W ramach Polsko-Niemieckiej Komisji Międzyrządowej funkcjonują cztery Komitety:

- Komitet ds. Współpracy Przygranicznej,

- Komitet ds. Współpracy Międzyregionalnej,

- Komitet ds. Edukacji,

- Komitet ds. Gospodarki Przestrzennej.

W Komunikacie z XXIII posiedzenia Komisji122 zaakcentowano aktualnie najważniejszą problematykę, która dotyka pogranicza polsko-niemieckiego. Na szczególną uwagę zasługuje:

- infrastruktura kolejowa,

- poprawa sytuacji na drogach wodnych pogranicza,

- problem powołania nowej grupy roboczej ds. usprawnienia współpracy transgranicznej przy zapobieganiu i zwalczaniu skutków klęsk żywiołowych,

- wymiana danych medycznych w ramach transgranicznej opieki nad pacjentami,

118 Została podpisana w listopadzie 2012 roku przez Ministra Transportu, Budownictwa i Gospodarki Morskiej, aktualnie przebiega dalszy proces jej ratyfikacji.

119 Porozumienie między Rządem Rzeczypospolitej Polskiej a Rządem Republiki Federalnej Niemiec o utworzeniu Polsko-Niemieckiego Centrum Współpracy Służb Granicznych, Policyjnych i Celnych, zawarte dnia 17 lutego 2011 r. (Dz.U. z 2012 r., poz. 1252) - Centrum działa de facto od 20 grudnia 2007 r. - patrz: http://www.nadodrzanski.strazgraniczna.pl/pncw-swiecko.html

120 Tryb dostępu oficjalna strona internetowa Ministerstwa Spraw Wewnętrznych: msw.gov.pl/download/1/10985/ REGULAMIN.pdf, dnia 07.12.2012 r.

121 Tryb dostępu oficjalna strona internetowa Ministerstwa Spraw Wewnętrznych: msw.gov.pl/download/1/10984/ NOTA.pdf, dnia 07.12.2012 r.

122 Tryb dostępu oficjalna strona internetowa Ministerstwa Spraw Wewnętrznych: msw.gov.pl/download/1/15489/ Komunikat_XXIII_posiedzenia_Komisji.pdf, dnia 07.12.2012 r. 
- przygotowanie programów EWT w nowej perspektywie finansowej UE 2014-2020,

- kwestie dotyczące współpracy w dziedzinie energii i polityki klimatycznej oraz swobodnego przepływu pracowników i utrzymania uczciwych miejsc pracy,

- aktualizacja i tworzenie nowych projektów z dziedziny transgranicznej gospodarki przestrzennej,

- strategia rozwoju języka polskiego jako ojczystego obywateli niemieckich polskiego pochodzenia w RFN,

- inicjatywa Dnia Polsko-Niemieckiego,

- podręcznik do nauczania historii.

\section{Współpraca transgraniczna z Republiką Słowacji}

Współpraca w ramach Polsko-Słowackiej Komisji Międzyrządowej ds. Współpracy Transgranicznej odbywa się na podstawie Porozumienia między rządem Rzeczypospolitej Polskiej i Republiki Słowackiej o współpracy transgranicznej z dnia 18 sierpnia 1994 r. $^{123}$

W art. 7 pkt 1 Porozumienia czytamy:

„W celu badania i rozwiązywania problemów wspólnego zainteresowania władz regionalnych i lokalnych obu Państw oraz wspierania kontaktów między państwowymi i niepaństwowymi podmiotami na obszarach po obu stronach granicy polsko-słowackiej, Strony utworzą Polsko-Słowacką Komisję Międzyrządową do spraw Współpracy Transgranicznej, zwaną dalej „Komisjąa”.

Funkcjonowanie Komisji uregulowane jest Statutem sporządzonym 6 września 1996 r. i przyjętym przez Radę Ministrów w dniu 21 października 1996 r. ${ }^{124}$

W ramach Komisji funkcjonują następujące grupy robocze (w tym trzy zawieszone):

- ds. transgranicznych połączeń komunikacyjnych,

- ds. współpracy gospodarczej,

- ds. ochrony środowiska i gospodarki leśnej,

- ds. planowania przestrzennego i budownictwa,

- ds. pracy i polityki socjalnej,

123 Tryb dostępu oficjalna strona internetowa Ministerstwa Spraw Wewnętrznych: msw.gov.pl/download/1/10996/ POROZUMIENIE.pdf, na dzień 07.12.2012 r.

124 Tryb dostępu oficjalna strona internetowa Ministerstwa Spraw Wewnętrznych: msw.gov.pl/download/1/10997/ UCHWALA_STATUT.pdf, na dzień 07.12.2012 r. 
- ds. współpracy i wzajemnej pomocy podczas katastrof i klęsk żywiołowych lub innych poważnych wypadków,

- ds. zdrowia i ratownictwa medycznego,

- ds. współpracy przygranicznej samorządu terytorialnego,

- ds. kultury (działalność grupy została zawieszona),

- ds. oświaty i współpracy młodzieży oraz nauki i szkolnictwa wyższego (działalność grupy została zawieszona),

- ds. rolnictwa i gospodarki żywnościowej (działalność grupy została zawieszona).

W kilku ostatnich latach nie zaistniała potrzeba podpisania nowych porozumień czy też umów między oboma państwami. Współpraca aktualnie skupia się na realizacji zawartych już umów bilateralnych. Jako przykład można wskazać budowę mostu granicznego między miejscowością Piwniczna po stronie polskiej, a miejscowością Mniszek nad Popradem po stronie słowackiej. ${ }^{125}$

W Protokole ${ }^{126} \mathrm{z}$ ostatniego XVIII posiedzenia Polsko-Słowackiej Komisji Międzyrządowej ds. Współpracy Transgranicznej, które odbyło się 28-29 listopada 2012 r. w Stropkovie, poruszono następującą problematykę:

- polsko - słowackich transgranicznych połączeń komunikacyjnych i sytuacji na wspólnej granicy, w tym połączeń drogowych S69/D3, S19/R4, połączeń kolejowych, rozkładów jazdy, częstotliwości połączeń i ograniczeń w ruchu towarowym;

- planowania przestrzennego i budownictwa - informacji nt. wyników projektu INFRAREGTUR „Infrastrukturalne i organizacyjne możliwości poprawy dostępności przestrzennej jako czynnik rozwoju polsko - słowackich regionów turystycznych";

- ochrony środowiska i gospodarki leśnej, w szczególności zwiększenia skuteczności ochrony transgranicznej populacji dużych ssaków drapieżnych;

- tworzenia Europejskich Ugrupowań Współpracy Terytorialnej ${ }^{127}$ na polsko-słowackim obszarze przygranicznym, w tym trwającego procesu rejestracji EUWT Tatry oraz powstania EUWT Tritia;

125 Na podstawie Umowy między Rządem Rzeczypospolitej Polskiej a Rządem Republiki Słowackiej o budowie nowego połączenia drogowego i mostu granicznego przez rzekę Poprad w rejonie miejscowości Piwniczna i Mniszek nad Popradem podpisana w Ostrawie dnia 23 listopada 2004 r. (M.P. Nr 11, poz. 143 i 144) - umowa ta nie została zrealizowana zgodnie z terminem (2006 r.), aktualnie przewiduje się zakończenie inwestycji na 2014 lub $2015 \mathrm{r}$.

126 Tryb dostępu oficjalna strona internetowa Ministerstwa Spraw Wewnętrznych: www.msw.gov.pl/download/1/15805/Stropkov_2012_Protokol_i_zalaczniki_z_XVIII_posiedzenia_PolskoSlowackiej_Komisji.pdf, na dzień 07.12.2012 r.

127 Na podstawie Ustawy z dnia 7 listopada 2008 r. o europejskim ugrupowaniu współpracy terytorialnej (Dz.U. z 2008 r. Nr 218, poz. 1390). 
- polsko-słowackiej współpracy transgranicznej województwa śląskiego i Żylińskiego Kraju Samorządowego,

- współpracy i wzajemnej pomocy podczas katastrof i klęsk żywiołowych lub innych poważnych wypadków, w kwestii aktualizacji „Instrukcji metodycznej dot. współpracy jednostek straży pożarnych RP z korpusem Pożarniczo-Ratowniczym i jednostkami straży pożarnych RSŁ przy udzielaniu pomocy wzajemnej";

- współpracy gospodarczej;

- przeciwdziałania bezrobociu $\mathrm{w}$ polsko-słowackim regionie przygranicznym i polityki społecznej - upowszechniania pośród pracodawców, instytucji i mieszkańców regionów wiedzy o możliwościach zatrudniania po obu stronach granicy, rozpoznania możliwości wsparcia transgranicznych programów zatrudnienia z funduszy celowych obu krajów, utworzenia partnerstwa na Transgranicznym Rynku Pracy podregionu nowosądeckiego i Kraju Preszowskiego;

- możliwości aktywowania, z inicjatywy każdej ze stron, prac grupy roboczej ds. zdrowia i ratownictwa medycznego, gdy zajdzie potrzeba omówienia kwestii: chorób zawodowych, niepełnosprawności sprzężonej, leczenia uzdrowiskowego.

Komisja na XVIII posiedzeniu, zatwierdziła regulamin pracy grup roboczych działających w ramach Komisji. ${ }^{128}$

\section{Współpraca transgraniczna z Ukrainą}

Transgraniczna współpraca Rzeczypospolitej Polskiej z Ukrainą opiera się na kilku aktach prawnych. Pierwszym, który poruszał problematykę współpracy transgranicznej między oboma państwami, był Traktat o dobrym sąsiedztwie, przyjaznych stosunkach i współpracy. ${ }^{129}$

W art. 10 Traktatu, czytamy:

„1. Strony będą sprzyjać ustanowieniu i rozwojowi bezpośrednich kontaktów i współpracy między regionami, jednostkami administracyjno-terytorialnymi i miastami Rzeczypospolitej Polskiej i Ukrainy. Szczególna uwaga będzie poświęcona współpracy w obszarach przygranicznych. Strony będą współpracować w dziedzinie perspektywicznego planowania rozwoju regionów przygranicznych.

128 Tryb dostępu oficjalna strona internetowa Ministerstwa Spraw Wewnętrznych: www.msw.gov.pl/download/1/15805/Stropkov_2012_Protokol_i_zalaczniki_z_XVIII_posiedzenia_PolskoSlowackiej_Komisji.pdf - załącznik nr 2, dnia 07.12.2012 $\mathrm{r}$.

129 Traktat między Rzeczpospolitą Polską a Ukrainą o dobrym sąsiedztwie, przyjaznych stosunkach i współpracy, sporządzony w Warszawie dnia 18 maja 1992 r. (Dz.U. z 1993 r. Nr 125, poz. 573). 
2. W celu realizacji tych ustaleń będzie utworzona Komisja Międzyrządowa do spraw Współpracy Międzyregionalnej."

Kolejnym ważnym aktem dla współpracy transgranicznej tych państw jest Porozumienie między Rządem Rzeczypospolitej Polskiej a Rządem Ukrainy o współpracy międzyregionalnej sporządzone w Kijowie 24 maja 1993 r. ${ }^{130}$ Art. 6 Porozumienia konstatuje:

„Strony utworzą wspólną Międzyrządową Radę Koordynacyjną do spraw Współpracy Międzyregionalnej”.

Pomimo rozbieżności w nazewnictwie gremium międzyrządowego w obu powyższych aktach prawnych, nie ma wątpliwości co do intencji umawiających się stron odnośnie utworzenia tylko jednego gremium zajmującego się współpracą transgraniczną.

Funkcjonowanie Polsko-Ukraińskiej Międzyrządowej Rady Koordynacyjnej ds. Współpracy Międzyregionalnej zostało uregulowane Statutem z dnia 26 stycznia 1996 r. $^{131}$

W ramach Rady funkcjonują następujące Komisje:

- Komisja ds. współpracy transgranicznej;

- Komisja ds. przejść granicznych i infrastruktury;

- Komisja ds. planowania przestrzennego;

- Komisja ds. ratownictwa i ochrony ludności w warunkach nadzwyczajnych zagrożeń (powołana na X posiedzeniu Rady).

Ostatnie, X posiedzenie Polsko-Ukraińskiej Rady Międzyrządowej odbyło się w dniach 28-29 marca 2012 r. w Warszawie. W Protokole ${ }^{132}$ z posiedzenia poruszono następujące kwestie:

- rozwój i modernizację infrastruktury komunikacyjnej pogranicza polsko-ukraińskiego w związku z przygotowaniem finału Mistrzostw Europy w Piłce Nożnej EURO 2012; możliwości budowy i modernizacji dróg krajowych do przejść granicznych na polsko-ukraińskiej granicy państwowej (w tym autostrady A4),

- podejmowanie przez służby Wojewody Podkarpackiego działań w zakresie zapewnienia bezpieczeństwa podróżnych przekraczających granicę polsko-ukraińską,

\footnotetext{
130 Tryb dostępu oficjalna strona internetowa Ministerstwa Spraw Wewnętrznych: www.msw.gov.pl/download/1/10999/Porozumienie.pdf, dnia 07.12.2012 r.

131 Tryb dostępu oficjalna strona internetowa Ministerstwa Spraw Wewnętrznych: www.msw.gov.pl/download/1/11000/Statut.pdf, na dzień 07.12.2012 r.

132 Tryb dostępu oficjalna strona internetowa Ministerstwa Spraw Wewnętrznych: www.msw.gov.pl/download/1/14349/protokol_i_zalaczniki_skan.pdf, dnia 07.12.2012 r.
} 
- rozdzielenie ruchu osobowego od towarowego w drogowym przejściu granicznym Korczowa - Krakowiec,

- zaawansowanie prac nad zmianami w Kodeksie Granicznym Schengen wspólne kontrole na terytorium państw trzecich,

- polsko-ukraińską współpracę w zakresie ratownictwa i ochrony ludności w warunkach nadzwyczajnych zagrożeń,

- wykorzystania funduszy europejskich do rozwoju współpracy przygranicznej między Polską i Ukrainą,

- rozwój współpracy międzyregionalnej realizowanej przez jednostki administracyjno-terytorialne Polski i Ukrainy, w szczególności jednostki terytorialne województwa świętokrzyskiego i obwodu winnickiego.

Podsumowując powyższe informacje, należy zauważyć zarówno zróżnicowanie tematyki i prac poszczególnych gremiów, jak i ich punkty wspólne. Pierwszym punktem styczności jest to, iż wszystkie powyższe gremia działają na zasadzie ciała ogólnego i jego wyspecjalizowanych grup. Ten ogólny schemat ulega jednak silnemu zróżnicowaniu co do konkretnego podziału kompetencji i ich szczegółowości pomiędzy powyższymi komisjami i radami.

Dodatkowo wartą zauważenia jest sama tematyka, która co do zasady w dużej mierze powtarza się pomiędzy gremiami, jednocześnie zachowując swoją specyfikę, wynikającą ze zróżnicowania problemów na poszczególnych granicach. Warte podkreślenia jest, jak ważną rolę dla strony samorządowej i rządowej w każdym z powyższych gremiów zajmuje problematyka infrastruktury transportowej. Jej priorytetowy charakter wynika z wieloletniej skali zaniedbania tej kwestii w przeszłości. Aktualnie zaniedbania te próbuje się nadrobić poprzez szereg inwestycji, których jednak nie da się zrealizować w satysfakcjonującym zainteresowane strony czasie. 


\section{THE CURRENT CROSS-BORDER COOPERATION OF THE REPUBLIC OF POLAND SHAPING THE INTERNATIONAL ACTIVITY OF LOCAL GOVERNMENTS}

The article is arranged in three parts:

\section{Introduction}

In the introduction to the article, the author describes the basic principles of cross-border cooperation, consisting of the definition of cooperation as described in the European Outline Convention on Transfrontier Co-operation Between Territorial Communities or Authorities. The author then discusses the basic rules of functioning of intergovernmental commissions and councils.

\section{Main body}

The main body of the article consists of discussion about recent cross-border cooperation issues with three chosen neighboring countries of the Republic of Poland: the Federal Republic of Germany, the Republic of Slovakia and Ukraine. Cooperation with the countries mentioned is made through:

- the Polish-German Intergovernmental Commission for Regional and Closeborder Cooperation;

- the Polish-Slovak Intergovernmental Commission for Cross-border Cooperation;

- the Polish-Ukrainian Intergovernmental Council for Interregional Cooperation.

All of the bodies mentioned are, from the Polish side, under the supervision of the Ministry of Interior of the Republic of Poland.

\section{Summary}

In the summary of the article, the author stresses the similarities and differences in bilateral cooperation of the Republic of Poland and its neighbors.

Keywords:

Transboundary cooperation, interregional intergovernmental commision, council 